\title{
Revitalizing Local Wisdom in Balinese Simile: An Effort to Enhance Balinese Youth Character
}

\author{
I Nyoman Kardana \\ Faculty of Letters, Warmadewa University, Denpasar, Indonesia \\ I Gusti Ngurah Adi Rajistha \\ Faculty of Letters, Warmadewa University, Denpasar, Indonesia \\ Made Sri Satyawati \\ Faculty of Humanities, Udayana University, Denpasar, Indonesia
}

\begin{abstract}
The moral message in local languages is often referred to as local wisdom. Local wisdom plays a very important role in people's lives since it is used as a means and basis for solving their encountered various problems. As one of the big local languages in Indonesia, the Balinese language contains many figurative languages that are rich in local wisdom values. The values have proven to be a shield to protect the Balinese people and their culture from the globalization attack. For this reason, local wisdom found in Balinese figurative language needs to be revitalized to be understood and implemented by the younger generation of Bali. One of the figurative languages studied in this study is the simile. Similes of the Balinese language are studied by combining three approaches, namely ecolinguistic, pragmatic, and cultural approaches, to reach detailed analysis results. Simile as part of a metaphor is an expression or discourse conveyed by the speaker indirectly to the interlocutor with certain aims and objectives. The ecolinguistic approach examines the form, function, and meaning or ideology contained in metaphorical language. Meanwhile, a pragmatic approach and a cultural approach are used to assist the ecolinguistic approach in uncovering the functions of figurative language in society and explaining the meaning or ideology existing in Balinese society. The values were reviewed for relevance to the current people's lives contaminated by information technology and tourism development.
\end{abstract}

Index Terms-Balinese language, ecolinguistic, local wisdom, simile

\section{INTRODUCTION}

As part of Balinese culture, the Balinese language is a means of communication among the speakers and is also used as a medium to transfer various messages and moral values of Balinese people. For this reason, the Balinese language is worth maintaining and preserving so that the values contained in the language can be well maintained. The values found in some expressions of the language have existed since a hundred years ago, and the people have believed in the truth of the values, and up to now, the values have been recognized and used as guidelines in their social life. The values are identified in Balinese local wisdom. The local wisdom wrapped in the Balinese language is not always expressed in a direct form. Still, some are conveyed indirectly through a certain language style, which is often identified as figurative language, which contains non-literal meanings or not real meanings. Such language is often used to maintain language manners, convey certain moral messages, or keep the speech situation under control. The figurative language used in Balinese discourse needs to be revitalized so that the young Balinese generation can understand Balinese figurative language and the noble values used as the basis for their life in the current modern society.

The number of researches that reveal figurative language as a medium to wrap for moral, ethical, and other Balinese cultural values is still limited. Moreover, research that integrates several approaches to examine the form, function, meaning, and ideology that guides people's lives contained in Balinese figurative language is hardly found. So far, studies on Balinese figurative language have focused on one type of figurative, namely metaphor. It is known that many other figurative types have not been completely studied. One of them is the simile. Balinese simile is also considered to have a very high message and values concerning socio-cultural life. These values have been recognized as a part of Balinese culture and a way of life for Balinese people from the past. This is becoming important to study since, in the current situation, Bali has been attacked by a moral crisis, especially for the millennial generation. The local wisdom is expected to be the social guard to protect the young generation from global tourism and information technology development.

Balinese millennials seem to be very shackled by the rapid advances in information technology. Balinese people must immediately be aware of this phenomenon. One alternative solution that can help improve and develop the character of the younger generation is to increase their love for their local language. When they love and use their local language 
very well, they can understand the moral values. Values often found in simile can be well understood and used as the basic principle in their daily activities.

Several studies related to this research topic are described. Metaphor has traditionally been seen as the most widely and most frequently figurative that is used by people (Saeed, 1997). Metaphor is something similar to a metaphor (simile). Metaphor is something outside normal language and requires certain forms for listeners to interpret it. Arnawa analyzes the forms and references of metaphors in Balinese (Arnawa, 2016). He says that basically, the use of metaphors is motivated by the principles of cooperation and politeness. The research has not yet explored the function of each form of metaphor and what it has to do with the social life of the Balinese people. Rajistha examines the various metaphors in Balinese (Rajistha, 2016). However, his research has not revealed the relationship of form in its use and meaning of moral values contained in metaphor. Thus, its relation to the sociological and ideological aspects of the Balinese speaking community cannot be explained. Ponsonnet examines the correlation between figurative language and its conceptual representation that occurs due to language shift. Possonnet sees figurative language only from a pragmatic point of view (Ponsonnet, 2017).

Burgers, Lavalette, and Steen, examine metaphor, hyperbole, and irony in discourse texts (Burgers et al., 2018). Their research emphasizes the analysis in terms of the combination and collocation of the three figurative languages. In addition, their research focuses on the structure and does not touch on figurative language in an eco-pragmatic way. Carston reveals that mental imaging due to understanding a metaphor is not related to language understanding metaphorically, but it exists because of the linguistic and pragmatic process of the readers (Carston, 2018). Augé examines the structure of the concept of nurturing parents and strict fathers from a metaphorical point of view (Augé, 2019). Auge reveals that the metaphorical scenario applied to analyze the two concepts of nurturing parent and strict father revealed variations in meaning socio-culturally and linguistically. Jensen and Greve explain that metaphor is a product related to the organism-environment system. In this case, the metaphorical meaning of a metaphor is related and is a projection of organism and environment (Jensen \& Greve, 2019).

Adigüzel examines the metaphorical concept of love suffering associated with natural phenomena and natural disasters (Adıgüzel, 2020). He explains the relationship between concepts obtained from nature and the feelings felt by the human body. Salas-Zárate et al. study the use of figurative language on social media, and they reveal that the figurative language that is often used in social media is sarcasm (Salas-Zárate et al., 2020). Al-Azary, Gagné, and Spalding analyze conceptual metaphors related to human experience, especially those related to water and air, which are further explained as hydro-aero (Al-Azary et al., 2020). The research mapped metaphors related to hydro-aero based on their characteristics and structures and reveals that the natural lexicon is also used in metaphors. Winter, Duffy, and Littlemore examine the understanding of metaphors related to power, gender, and individual differences (Winter et al., 2020). This study emphasizes the influence of social class, gender, and individual characteristics on understanding metaphors, and it can be stated that the same metaphor can be interpreted differently.

This study is not only useful for maintaining the existence of Balinese among some foreign languages studied by people in Bali because of economic reasons. However, more than that, the introduction and understanding of human values that have existed for a long time wrapped in figurative language may positively impact the character improvement of the young Balinese generation.

\section{METHOD}

A research method plays an important role in research, considering that the method is a systematic way of working to achieve the expected purpose (Djajasudarma, 1993; Sudaryanto, 1993). This qualitative descriptive study aims to describe data related to the existing local community values. To make this study successful, data were collected by implementing the appropriate method. Data of this research are identified into spoken and written data related to the figurative discourse of the Balinese language. The spoken data were collected from Balinese language informants living in Bali. Informants were selected intentionally (purposive sampling) (Bungin, 2003). Some requirements due to get good informants to include: adult Balinese native speakers, mastering terms related to Balinese culture (including Balinese religion and customs), not much affected by other languages, be competent/intelligent, be capable of good language, have sufficient time, have mental readiness to become an informant, and have good articulation tools (Bawa, 1992; Samarin, 1988). These requirements are needed because not all speakers from different levels can master and use figurative language in their daily communication. The written data were obtained from several written works using the Balinese language. The written data were collected from some works in the form of folk tales widely well known by the people. The research data were collected through observation and interview methods assisted by recording and notetaking techniques.

\section{FINDING AND DISCUSSION}

\section{A. Local Wisdom in Balinese Simile}

Balinese similes are used to compare something with another form by using markers buka or cara 'like or as.' The study shows that Balinese similes can use references in the form of inanimate objects, animals, and plants from a biological aspect. From a sociological aspect, Balinese similes convey orders, requests, satire, praise, and suggestions. 
Then from the ideological perspective, the similes show that Balinese people are very close to their environment and appreciate their environment. Even the environment inspires people to understand moral values that need to be considered in their social life. Some examples of Balinese similes are as follows:

\section{Buka Be Bonane, Dawanan Bungut: 'Like the Bona Fish, Have Long Mouth'}

Simile in the form of noun phrase buka be bonane 'like the bona fish' with its denotative referent dawanan bungut 'to have long mouth' is a kind of simile to compare human with the bona fish metaphorically. This simile is often used to insinuate someone who wants to spread out what someone else says to other people and often adds some extra words to make other people get angry or disappointed. This act certainly does not show good behavior to follow, and people are advised to avoid such acts. The simile uses a type of fauna from a biological aspect, namely be bona 'bona fish.' Balinese people know such a type of fish with a long mouth, considering that this fish could be found in all waters area in Bali. Coastal communities often catch the fish and sell them in traditional markets. Because this type of fish is very familiar to people, the meaning of the simile is easy to understand widely. Viewed from the sociological aspect, the function of the simile is to insinuate someone or give advice or suggestion to others not to do the actions referred to by the parable or simile because it can damage one's relationship. This simile is often used to make someone bring into conflict with others. An example of its use can be seen in the following example.

Yen cening dot ngelah timpal liu, De cara be bonane, dawanan bungut.

'If you wish to have lots of friends, don't be like bona fish, with a long mouth.'

Meaning: If you want to make lots of friends, you may not talk unuseful words or unnecessary things about someone to others. This simile also means that we may not make someone conflict with others because of our behavior.

\section{Buka Bikule Pisuhin, Sumingkin Bejit: 'Like A Rat Is Cursed, It Is Getting Naughty/Wicked/Bad.}

The simile is a metaphor for cursed people. In fact, they are getting naughty and are increasingly unmanageable. This simile is useful for expressing satire, and it can even be used to advise others not to treat other people or their children, as described by the simile. It can be seen in the following example.

Ngajahin pianak anak nagih ati-ati, da kanti buka bikule pisuhin, sumingkin bejit.

Teaching teenagers should be careful, not to be like a cursed rat, it is getting naughty/wicked/bad/unmanageable.

Meaning: Be careful to teach young people, while we treat them hard, and as if they are cursed, they will be getting unmanageable/uncontrolled. Thus, we have to touch them softly and know their situation and condition well.

The suggestion conveyed through the simile is that we need to be careful in educating young people. If we treat them unwell or rant at them, they will become much naughtier and cannot be well controlled. Biologically, this simile is formed by the fauna bikul 'rat,' and the animal is very close to Balinese life and Indonesian agrarian society. Rats are animals that often destroy the rice plants, so that rats are given special behavior in Balinese life. To make rats not destroy the rice plants, Balinese people make special offerings on certain days to be specially offered to the God of the rat. With the holy offering, the people hope there is no massive rat attack on their rice plants. The people also have a special nickname for this animal. It is called Jero Ketut. This name is exactly a call name usually intended for highlevel people. Thus, if the rats are cursed, it is believed that something undesirable will happen, such as a massive attack on the farmers' rice. That is why the above simile is very popular in Balinese society.

\section{Buka Naar Kerupuke, Gedenan Kroakan 'Like Eating Crackers, It Sounds Loudly'.}

The meaning of the simile is like a person who claims himself to be smart, intelligent, and has a lot of experience, but in fact, he doesn't have the ability to do or complete any works provided to him very well. The simile is formed by the inanimate noun kerupuk 'Indonesian crackers,' a snack people like in Indonesia. Krupuk is a cheap and easily available meal and is often used as a side dish with rice for lunch and dinner by people living in rural and urban areas. When the crackers are eaten, there will be a sound, and even the sound is sometimes very loud. That is why people easily understand the connotative meaning of the simile. This figurative is often used to criticize someone or give advice to someone hoping that he does not act as stated in the simile. When the speakers use the simile to insinuate, the addressees do not feel hurt or angry because the satire is in the form indirect sentence. This can be seen in the following example.

Cai buka naar krupuk, gedenan kroakan

'You are like people who are eating crackers, big sound

Meaning: This simile expresses someone who works a little, but he says/claims much. He says to everyone that he has done many things, but in reality, he did nothing.

The example of the simile once occurred when a group of people was talking, and one of them said that he was an expert in many things and he was able to do various works well and perfectly so that many people wanted to hire him. However, the other speaker(s) knew him very well, especially about his capacity, contrary to what he said. Then, a speaker who was involved in the conversation said like a simile. 
This simile has also been very popular in Balinese society since a long time ago. From the biological aspect, jangkrik 'crickets' are animals or fauna very close to the rural Balinese people. The sound of crickets at night has been very familiar to the ears of Balinese people, especially those who live in the rural area. Currently, many young Balinese do not know the animal, and even people who live in urban areas whose homes are surrounded by asphalt and paving, almost have never heard the sound of crickets. They have never seen the animal anymore. The simile is often used to convey advice, advice, and also satire. An example of its use can be seen below.

Yen dadi idih bli, da cai cara jangkerike, galak di bungut dogen.

'If possible, don't be like a cricket, only dare to speak and never dare to execute anything.'

Meaning: We have to dare to do something or wish to do and not only dare to speak.

\section{Buka Payane, Disisi Maukir Ditengahne Ngasumba 'Like A Bitter Melon, The Skin Is Etched But The Inside Is Red'}

This simile is often used to insinuate someone whose behavior is not good. For instance, the way he talks is good and polite, but his mind is not good, and he even often wants to harm others. The simile is very important to teach the younger generation not to behave like what the simile express. Thus, the figurative of simile is often used to convey advice, suggestion, or tell others to be careful with someone who has the behavior as the simile metaphors. Seen from the biological aspect, the simile uses the noun buah pare 'bitter melon,' a vegetable fruit Balinese people often consume. Although it tastes bitter, many people like it. The real thing seen in people's lives related to the simile is that there are people whose appearance and way of speaking are good and attractive, but in fact, they have evil hearts, and they are full of envy and jealousy and can never accept others' success. The simile is still relevant for young people to know today. The example can be seen below.

Ati-ati ajak jelemane ento, ia anak tan perah irine teken keluarga iragane, ia sing bisa nolih anak len berhasil.

Yen umpamaang Ia nak buka payane, disisina dogen maukir sakewale ditengahne ngasumba.

'Be careful with that guy. He is indeed very jealous of our family, and he can't see other people get successful in their life. He is like a bitter melon whose performance/look is good and friendly, but not in his heart'.

Meaning: Someone who looks good, polite, and friendly does not always mean good and fine to everyone, but sometimes he feels bad to someone else because of some reason.

\section{Buka Goake, Ngadanin Ibane 'Like A Crow, Always Calls/Names Itself.'}

This simile uses goak 'crow,' a bird that is also familiar to the Balinese people. The color of this bird is black, and when flying, it always makes a sound, and its voice is loud enough, and people can hear it. Its sound is 'goak...goak...goak...' as its name in Balinese. I think that is the reason why the animal is used as a metaphor in Balinese. This simile is often used to insinuate or give advice to others. An example of the use of the simile is as follows.

Ia nak mula care goake, ngadanin ibane. Onyang sube nawang keto.

'He's like a crow who is naming or calling himself. Everyone has recognized him well.'

Meaning: It is like a person who claims himself (very) great, but the reality is contradictory.

\section{Buka Cicinge Ngongkong, Tuara Pingenan Nyegut 'Like A Barking Dog, Will Never Bite'.}

Various level people in Bali very well know this simile. From the biological aspect, the lexicon uses the animal name cicing 'dog' as one of the familiar animals in Bali. Everyone knows this animal since it is one of the Balinese family's favorite pets. Sociologically, in daily Balinese communication, the simile is often used as a form of satire. Insinuation conveyed indirectly by this simile is applied effectively as the person being insinuated is not angry or offended. That is because the simile contains a joke value. The example is as follows.

De cai takut. Ia anak care cicinge ngongkong, tuara pingenan nyegut.

'Don't be afraid. He is just like a barking dog that will never bite.'

Meaning: Someone who talks much usually does not do anything. So, we must not be deceived by the intelligence of a person who speaks a lot. Speaking a lot does not always mean being intelligent.

\section{Buka Macane, Nakutin Lawat Padidi 'Like A Tiger, Afraid Of His Own Shadow'}

The simile is used to describe someone who is worried or afraid of what he has done. The simile uses the lexicon macan 'tiger,' one of the wild animals the people know. The simile uses lexicon macan 'tiger' because the animal looks very scary, and it is depicted that the tiger himself was shocked and afraid when he saw his scary shadow. An example of the use of the simile is as follows.

Ia pepes ngae ugig di gumine, dadine ia buka macane, nakutin lawatne padidi. Sing taen juari kebale banjar.

'He often does bad things in society, so he is like a tiger who is afraid of his own shadow. That is why he never dared to come to the public hall.'

Meaning: Someone who frequently makes mistakes or makes others suffer. He usually feels ashamed to come to a public area. He is worried if others will bully him.

9. Buka Nakep Balange Dadua, Buka Dadua Tuara Bakat 'Like Catching Two Grasshoppers, Neither Can Be Successfully Caught.'

The simile is in the form of the simple clause nakep balange, 'catching grasshoppers.' Biologically, the simile uses 
the lexicon of balang 'grasshopper', one of the famous insects found in the rice field. Farmers in Indonesia often catch grasshoppers in their rice fields because, in addition to grasshoppers as pests of rice plants, the insects can also be used as a side dish. That is why the clause nakep balang, 'catching grasshoppers,' has become a very popular activity in Balinese society. The simile buka nakep balange dadua, buka dadua tuara bakat 'like catching two grasshoppers, neither can be successfully caught' is often used to convey advice and satire. The connotative meaning of the simile reflects a greedy person who wants to get two or more things simultaneously, but in fact, he gets nothing. The use of the simile can be seen below.

Yen dot berhasil, de cai buka anak nakep balang dadue, buka dadua nyanan tuara bakat.

'If you want to be successful at a work, don't be like catching two grasshoppers at once; neither can be caught.'

Meaning: Don't be a greedy man! We can not do a lot of things successfully at the same time. Success needs a

process. In doing something, we must focus on one job until we can get good and satisfactory results.

10. Buka Padine, Yening Misi Nguntul Tur Yening Puyung Nyeleg 'Like Rice Plant, When It Is Full, It Bends Down, And When It Is Empty It Stands Up.'

This simile is also related to Balinese life. Simile using lexicon padi 'rice' becomes popular since Balinese used to work as farmers and rice is too close to them. The simile is often used to convey advice. Giving advice indirectly with the simile is quite effective in the Balinese community. The connotative meaning found in the simile is: People who have a lot of knowledge will be silent and show more polite behavior. However, people who speak a lot and pretend to know many things usually have little knowledge and experience, often show bad behavior, and often appear arrogant. Balinese people prefer making friends with people who don't talk much, look polite, and have knowledge and experience. Balinese commonly do not like people who talk much, but in fact, they know nothing. The use of the simile can be seen in the following example.

Iraga mestine buka padine, ane misi nguntul, ane puyung nyeleg.

'We must be like a rice plant. When it is full, it bends down, and when it is empty, it stands up.

Meaning: We are not so proud when we are rich in money, intelligence, and experiences. Otherwise, we have to be polite, friendly and fine to everyone.

All of the presented examples of simile, when we analyze more closely, they contain a lot of local wisdom. The Balinese local wisdom is part of the local community knowledge that emerges from the adaptation of the Balinese community based on their daily life experiences, and the knowledge is communicated from generation to generation. However, today there is a lot of Balinese local wisdom that encounters some difficulties to transfer. Most of the younger generation do not know the local wisdom that has existed since several years ago. This becomes a serious problem to solve so that the local wisdom needs to be transferred to the next generation. This becomes very important considering that local wisdom is full of knowledge that contains meaning and messages that could guide people to survive and become gentle human beings with their character. Balinese social life that upholds local wisdom has made Bali very famous in the world. At the same time, Balinese people are also able to adapt to the immigrant people. Until now, Bali has become the best tourist destination in Indonesia for both foreign and domestic visitors.

The local wisdom that has been becoming the basis of Balinese life for many years are such as (1) Tri Hita Karana: values related to harmonization between human and God, between human and other humans, and between human and nature; (2) Tri Kaya Parisuda: the value of the unification of three elements, namely thinking, speaking, and behaving well; (3) Salunglung sabayantaka: social values related to equality and solidarity; (4) Tatwan Asi: values about mutual respect and respect for others; and (5) Manyama Braya: values about the importance of brotherhood and working together to finish works or to solve the encountered problems. These values teach us that humans as social beings are important to understand these values considering that humans cannot live alone without any helps and attention from others.

\section{B. Simile as a Platform to Enhance Balinese Youth Character}

Currently, Balinese people, especially the younger generation, tend to suffer moral degradation. This is one of the impacts of the rapid development of information technology and global community mobilization. The moral degradation of the young society is certainly a problem that needs to be solved immediately. One way that can be done is with a cultural approach. The cultural approach dealing with improving the morality and character of the community is through exploring the noble values of the community known as local wisdom. Local wisdom can be explored through local languages, one of which is through figurative language, in this study is the simile. This is the reason why it is important to preserve the local language.

Balinese simile contains many noble values that become the local wisdom of the community. Examples of similes discussed in this study have become evidence that Balinese communication often uses similes to convey certain messages like suggestions, advice, and satire. Balinese community creates simile in a certain way to avoid conflict or offense when they intend to give each other advice, suggestion, and satire. The use of simile as an indirect way is effective in Balinese society. Basically, the use of simile is motivated by the principles of cooperation and politeness in communication. For this reason, the use of similes needs to be preserved and developed in the life of modern society currently. 
In another way, the young generation's understanding of Balinese towards figurative language needs to be improved so that they can use figurative language, including similes, in conveying certain messages when communicating in Balinese. This is a good strategy to improve the character of the young Balinese generation. This is why the local wisdom of Balinese related to moral and ethical learning that has been tested since ancient times needs to be preserved for the younger generation in the future.

\section{CONCLUSION}

Balinese people have a lot of local wisdom that has grown up and developed for a long time. The local wisdom has become the frame and basis of Balinese socio-cultural life. A lot of local wisdom is stored in the local language, likewise in the Balinese language. For instance, Balinese similes contain many noble values that are now identified as local wisdom. Messages that are often conveyed through simile are in the form of suggestions, advice, and satire. The community creates simile as a means to transfer moral values to one another. The form of simile as an indirect way of giving advice, suggestion, and advice or satire to others is very effective in society.

For this reason, the use of simile and other kinds of figurative needs to be preserved and developed and continued in the life of modern society today. Seen from its form, Balinese simile can use the lexicon of both animate and inanimate objects. The study results found that the connotative meaning contained in all similes indicates that Balinese people are so close to their environment, and they need harmonization in life and prioritize politeness in speaking and doing something.

\section{ACKNOWLEDGMENTS}

We would like to thank the Rector of Warmadewa University for the research grant in the academic year 2021. We also would like to thank A. A Raka (the expert of Balinese culture), Jro Mangku Jasa (the priest of Balinese family temple), Nyoman Kertiasih (a housewife in a traditional village), I Ketut Darmaja (a farmer), and other Balinese friends for being informants in this study.

\section{REFERENCES}

[1] Adigüzel, M. F. (2020). Metaphoric Conceptualization of Love Pain or Suffering in Turkish Songs through Natural Phenomena and Natural Disasters. Metaphor and Symbol, 35(1), 56- 72. https://doi.org/10.1080/10926488.2020.1712784

[2] Al-Azary, H., Gagné, C. L., \& Spalding, T. L. (2020). From the Sea to the Sky: Metaphorically Mapping Water to Air. Metaphor and Symbol, 35(3), 206-219. https://doi.org/10.1080/10926488.2020.1804809

[3] Arnawa, N. (2016). Interpretasi Pragmatis Analogis Metafora Bahasa Bali” dalam Jurnal Kajian Bali (Vol. 06, Issue mor 01).

[4] Augé, A. (2019). How Metaphor Scenarios Reveal Socio-cultural and Linguistic Variations of Meaning: A Cross-linguistic Perspective on the "NURTURING PARENT" and the "STRICT FATHER" Frames. Metaphor and Symbol, 34(4), $209-228$. https://doi.org/10.1080/10926488.2019.1683949

[5] Bawa, I. W. (1992). Kalimat Aktif Bahasa Bali. Universitas Udayana.

[6] Bungin, B. (2003). Analisis Data Penelitian Kualitatif. PT Raja Grafindo Persada.

[7] Burgers, C., Lavalette, K. Y. R. d., \& Steen, G. J. (2018). Metaphor, hyperbole, and irony: uses in isolation and in combination in written discourse. Journal of Pragmatics, 127, 71-83.

[8] Carston, R. (2018). Figurative Language, Mental Imagery, and Pragmatics. Metaphor and Symbol, 33(3), $198-217$. https://doi.org/10.1080/10926488.2018.1481257

[9] Djajasudarma, T. F. (1993). Metode Linguistik: Ancangan Metode Penelitian dan Kajian. Eresco.

[10] Jensen, T. W., \& Greve, L. (2019). Ecological Cognition and Metaphor. Metaphor and Symbol, 34(1), 1-16. https://doi.org/10.1080/10926488.2019.1591720

[11] Ponsonnet, M. (2017). Conceptual representations and figurative language in language shift: Metaphors and gestures for emotions in Kriol (Barunga, northern Australia. Cognitive Linguistics, 28(4), 631-671. https://doi.org/10.1515/cog-2016-0020

[12] Rajistha, I. G. N. A. (2016). Beblabadan Bahasa Bali dalam Perspektif Ekolinguistik. RETORIKA: Jurnal Ilmu Bahasa, 2(1), 79-94.

[13] Saeed, J. I. (1997). Semantics. Blackwell Publishers Inc.

[14] Salas-Zárate, M. de. P., Alor-Hernández, G., Sánchez-Cervantes, J. L., Paredes-Valverde, M. A., García-Alcaraz, J. L., \& Valencia-García, R. (2020). Review of English literature on figurative language applied to social networks. Knowl Inf Syst, 63, 2105-2137. https://doi.org/10.1007/s10115-019-01425-3

[15] Samarin, W. Y. (1988). Ilmu bahasa lapangan. Kanisius.

[16] Sudaryanto. (1993). Metode dan Teknik Analisis Bahasa. Duta wacana University Press.

[17] Winter, B., Duffy, S. E., \& Littlemore, J. (2020). Power, Gender, and Individual Differences in Spatial Metaphor: The Role of Perceptual Stereotypes and Language Statistics. Metaphor and Symbol, 35(3), 188-205. https://doi.org/10.1080/10926488.2020.1794319. 


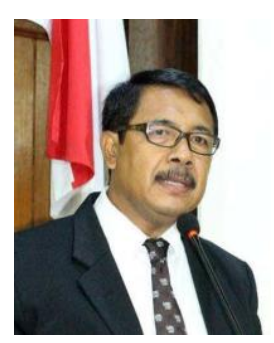

I Nyoman Kardana is a professor in Linguistics at Faculty of Letters Warmadewa University, Bali Indonesia. He received his Master Degree in Linguistics from Padjadjaran University, Bandung, Indonesia in 1998. He obtained his Doctorate Degree in Linguistics from Udayana University, Bali, Indonesia in 2004. He has been doing some researches related to the topics about morpho-syntax, semantics, and eco-linguistics. He has supervised many papers, theses and doctorate dissertations. He has also written a lot of articles published in national and international journals. He has participated in a number of national and international seminars as well.

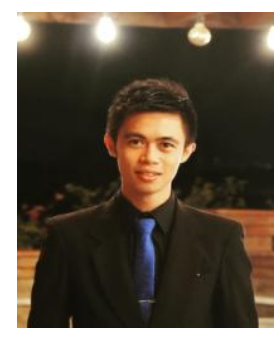

I Gusti Ngurah Adi Rajistha is a lecturer at English Literature Department, Faculty of Letters, Warmadewa University, Bali Indonesia. He got his bachelor and master degrees from Warmadewa University. He has done some studies on linguistics and published his research articles in national and international journals. In addition, he also has joined various the national and international conferences related to linguistics.

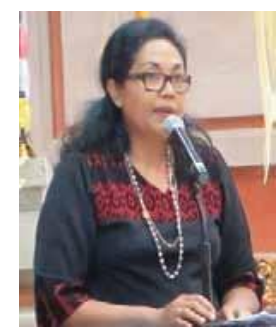

Made Sri Satyawati is a lecturer at Indonesian Department, Faculty of Humanities, Udayana University, Bali, Indonesia. She obtained her Master Degree in Linguistics from Padjadjaran University, Bandung, Indonesia in 1999 and she got her Doctorate Degree in Linguistics from Udayana University in 2010. Her research interest is in linguistics and she has conducted some researches about syntax, typology, and semantics. Her publications involve study on Indonesian language and some local languages in Eastern Indonesia. She has supervised many bachelor papers, theses and doctorate dissertations. She has also participated as guest and invited speaker in a number of national and international seminars. 